\title{
Survival of Patients With Testicular Cancer in Lithuania During 1999-2002
}

\author{
Agnius Juška ${ }^{1}$, Albertas Ulys ${ }^{2}$, Laura Kairevič $\dot{e}^{3}$, Giedrè Smailyte் $\dot{4}^{4}$ Edgaras Stankevičius ${ }^{5}$, \\ Rasa Jančiauskiené ${ }^{3}$, Mindaugas Jievaltas ${ }^{6}$
}

\begin{abstract}
${ }^{1}$ Faculty of Medicine, Vilnius University, ${ }^{2}$ Oncosurgery Center, Institute of Oncology, Vilnius University, ${ }^{3}$ Department of Oncology, Medical Academy, Lithuanian University of Health Sciences, ${ }^{4}$ Cancer Control and Prevention Center, Institute of Oncology, Vilnius University, ${ }^{5}$ Department of Physiology, Medical Academy, Lithuanian University of Health Sciences, ${ }^{6}$ Department of Urology, Medical Academy, Lithuanian University of Health Sciences, Lithuania
\end{abstract}

Key words: testicular cancer; survival; Kaplan-Meier method; log-rank test.

Summary. The aim of this study was to evaluate the survival of patients with testicular cancer in Lithuania during 1998-2002 and factors that influenced the survival.

Material and methods. The survival rates of testicular cancer patients were evaluated using the data of the Lithuanian Cancer Registry for 1998-2002. The survival was evaluated using the Kaplan-Meier method and log-rank test in order to compare the survival rates. The observed survival rates were calculated.

Results. The 5-year observed survival rate in Lithuania was 71.2\% (95\% CI, 64.4\%-77.5\%). The survival of testicular cancer patients depended on age at the time of diagnosis, histology of tumor, stage and extent of disease.

Conclusions. The survival of patients with testicular cancer in Lithuania was substantially lower than in other European countries. The better survival was associated with younger age and lesser extent of metastases.

\section{Introduction}

Testicular cancer (TC) is a rare malignant disease. Every year, an average of 49000 new TC cases are diagnosed worldwide. It constitutes $0.8 \%$ of all malignant diseases in men $(1,2)$. The morbidity rate of TC in Lithuania is relatively low; in 1995, it accounted for 1.6 cases per 100000 men (3). The highest morbidity rates have been observed in Western Europe (7.9 cases per 100000 population), Northern Europe, Australia and New Zealand, as well as North America (5.4 cases per 100000 population). The lowest morbidity rates due to $\mathrm{TC}$ are in Asia, e.g., in the Republic of China, the rate of TC accounts for 0.4 cases per 100000 population $(1,2)$. The incidence of TC in Europe doubles every 20 years (4). Recently, a dramatic increase in TC morbidity has been reported from many countries. The causes of this trend are not known. The improvement of diagnostics may explain only a small part of this increase. Contrary to the morbidity rate, the death rate due to TC has been declining since the 1960s (1) and is very low (3.8 cases per 100000 per year) (4).

In western countries, TC constitutes from $1 \%$ to $3 \%$ of all malignant tumors in men; however, in most European countries, it is the most common malignant disease among young men aged 15 to 34 years (5). The highest mortality rate is observed among men aged 15 to 44 years, and in this age group, TC is the most common malignant disease in the developed countries (constitutes 13.4\% of all new cancer cases). Testicular cancer is rarely responsible for death (9000 death cases worldwide). Over the last decades, positive outcomes of therapy have been associated with appropriate treatment using modern chemotherapy.

The survival of patients with TC in Lithuania has not been studied yet. The aim of our study was to evaluate the 5-year survival of patients diagnosed with TC during 1998-2002 as well as the factors influencing the survival.

\section{Material and Methods}

A retrospective descriptive study was carried out. The analysis of the survival was carried out using the data of the Lithuanian Cancer Registry. A total of 184 cases of TC were recorded in the database from December 1, 1998, to December 31, 2002. During this period, the fourth edition of the TNM system was used for coding the stage of disease. One 
case of TC was excluded from the analysis because the disease was registered after patient's death only (the date of the first diagnosis was equal to the date of death). The overall survival of patients with TC as well as survival dependence on histological form of the tumor (seminoma/nonseminoma), stage, size, and the extent of spread of the tumor, and patient's age were studied. The starting point of the evaluation of survival time was defined as the date of the first diagnosis; the closing date was defined as the date of the end of follow-up (December 31, 2008) or the date of patient's death. Patient survival was evaluated by categories using the Kaplan-Meier method, and log-rank test was used for statistical comparison of the categories. Differences were considered significant when $P$ value was $<0.05$. Statistical analysis was carried out using STATA 7.0 software.

\section{Results}

The analysis of the survival included 183 patients who were diagnosed with TC from January 1, 1998, to December 31, 2002. The mean follow-up was 6.03 years (range, 0.008-10.63). During the followup, of the 183 patients, 55 died and 128 patients were alive at the end of the follow-up. Table 1 presents the distribution of patients by age and pathological and clinical characteristics of the tumor.

The 1-year survival of all patients with TC was $83.1 \%$ (95\% CI, 76.8\%-87.8\%), and the 5-year survival reached $71.2 \%$ (95\% CI, 64.4\%-77.5\%). The observed survival is shown in Fig. 1. Table 2 presents the 5-year survival of patients by age and pathological and clinical characteristics of the tumor.

Age. The 5-year survival rates for patients aged 15-29, 30-44, 45-64, 65 and more years were $71.4 \%, 79.6 \%, 56.5 \%$, and $49.2 \%$, respectively (Fig. 1). Patient's age at the time of diagnosis had a significant impact on the survival rate $(P=0.02)$. The 5-year survival of patients older than 45 years was lower than $60 \%$, while that of patients younger than 45 years exceeded 70\%. Remarkably, patients aged 15-29 years demonstrated poorer survival than for those aged 30-44 years.

Tumor Histology. The survival rate for patients who were diagnosed with testicular seminomas was higher $(80.7 \%)$ as compared with those diagnosed with nonseminomas $(67.0 \%)$. The impact of histological form of the tumor on the survival was statistically significant ( $P=0.0003$ ) (Fig. 2).

Stage. The stage of diagnosed disease had a significant effect on the patient survival $(P<0.0001)$ (Fig. 3). The 5-year survival of the patients who were diagnosed with stage I cancer was $91.2 \%$, while these rates were almost two-fold lower - less than 50\% - in those with advanced disease (stages III and IV).

Tumor size. The 5-year survival was $89.4 \%$ when tumor T stage was T1, but when tumor was charac-
Table 1. The Distribution of Patients by Demographical, Pathological, and Clinical Characteristics

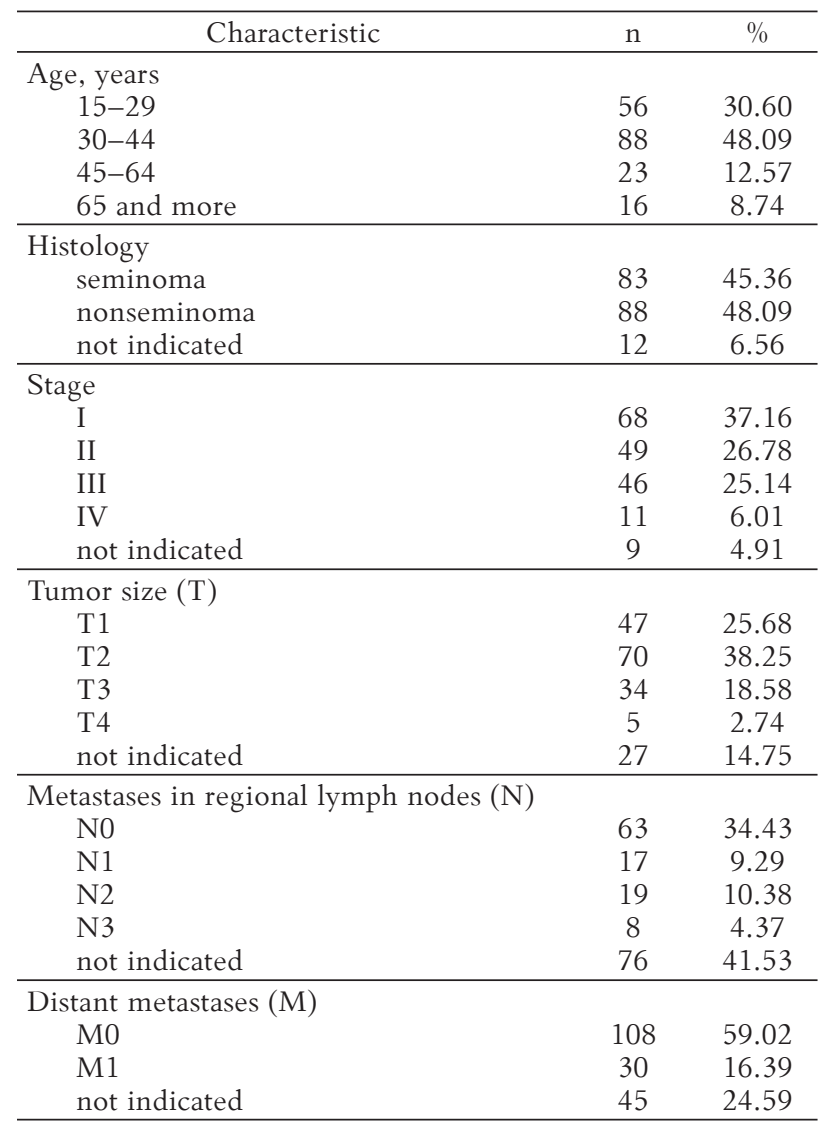

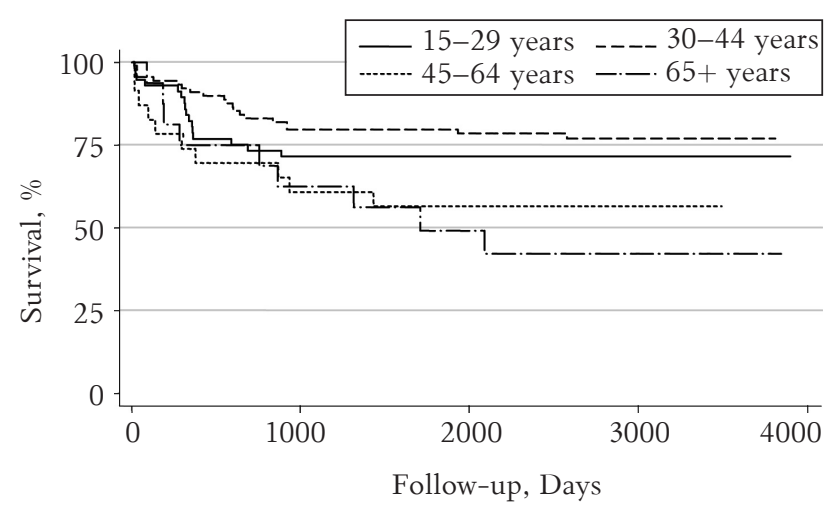

Fig. 1. The 5-year survival of patients with testicular cancer in Lithuania during 1998-2002 by age

terized as $\mathrm{T} 2$ at the time of diagnosis, the survival was $80.0 \%$. When tumor $\mathrm{T}$ stage was $\mathrm{T} 3$ and $\mathrm{T} 4$, the survival rates were $50.0 \%$ and $60.0 \%$, respectively. The higher survival rate when tumor stage was T4 may be influenced by other factors such as the number of infiltrated lymph nodes or the presence of distant metastases. The impact of tumor $\mathrm{T}$ stage on the 5-year survival was found to be statistically significant $(P<0.0001)$ (Fig. 4). 
Table 2. The 5-year Survival of Patients Diagnosed With Testicular Cancer in Lithuania During 1998-2002 by Demographical, Pathological, and Clinical Characteristics

\begin{tabular}{lcc}
\hline \multicolumn{1}{c}{ Characteristic } & Survival, \% & $95 \%$ CI \\
\hline Age, years & & \\
15-29 & 71.4 & $57.7-81.4$ \\
30-44 & 79.6 & $69.5-86.6$ \\
45-64 & 56.5 & $34.3-73.8$ \\
65 and more & 49.2 & $23.6-70.6$ \\
\hline Histology & & \\
seminoma & 80.7 & $70.42-87.7$ \\
nonseminoma & 67.0 & $56.2-75.8$ \\
not indicated & 41.7 & $15.3-66.5$ \\
\hline Stage & & \\
I & 91.2 & $81.4-95.9$ \\
II & 73.6 & $58.6-83.6$ \\
III & 47.8 & $32.9-61.3$ \\
IV & 45.5 & $16.7-70.7$ \\
not indicated & 64.8 & $25.3-87.2$ \\
\hline Tumor size (T) & & \\
T1 & 89.4 & $76.3-95.4$ \\
T2 & 80.0 & $68.5-87.6$ \\
T3 & 50.0 & $32.4-65.3$ \\
T4 & 60.0 & $12.6-88.2$ \\
not indicated & 47.9 & $28.3-65.0$ \\
\hline Metastases in regional lymph & & \\
nodes (N) & & \\
N0 & 87.3 & $76.2-93.4$ \\
N1 & 64.7 & $37.7-82.3$ \\
N2 & 42.1 & $20.4-62.5$ \\
N3 & 62.5 & $22.9-86.1$ \\
not indicated & 68.4 & $56.7-77.6$ \\
\hline Distant metastases (M) & & \\
M0 & 87.0 & $79.1-92.1$ \\
M1 & 33.3 & $17.5-50.0$ \\
not indicated & 59.9 & $44.2-72.5$ \\
\hline
\end{tabular}

Metastases in Regional Lymh Nodes. The presence of metastases in regional lymph nodes also had a significant impact on the 5-year survival $(P=0.0013)$. The highest survival rate $(87.3 \%)$ was observed when nodal metastases were absent (N0). Discrepancy between survival rate and an increase in the number of metastatic lymph nodes $(\mathrm{N})$ might be associated with the accuracy of evaluation of lymph nodes at the time of diagnosis.

Distant Metastases. When distant metastases were not present, the 5-year survival of those diagnosed with TC was $87.0 \%$. Meanwhile, this rate was $33.3 \%$ for those who had distant metastases at the time of TC diagnosis. The presence or absence of distant metastases was a major determinant for the 5-year survival $(P<0.0001)$.

\section{Discussion}

The majority of TCs (about 95\%) are germ cell tumors that derive from testicular epithelium, and almost all of them are malignant. The overwhelming majority of germ cell tumors are localized in the testes; rarely primary tumors develop extragenitally (retroperitoneal space, mediastinum, brain, and others). However, the major part of germ cell tumors account

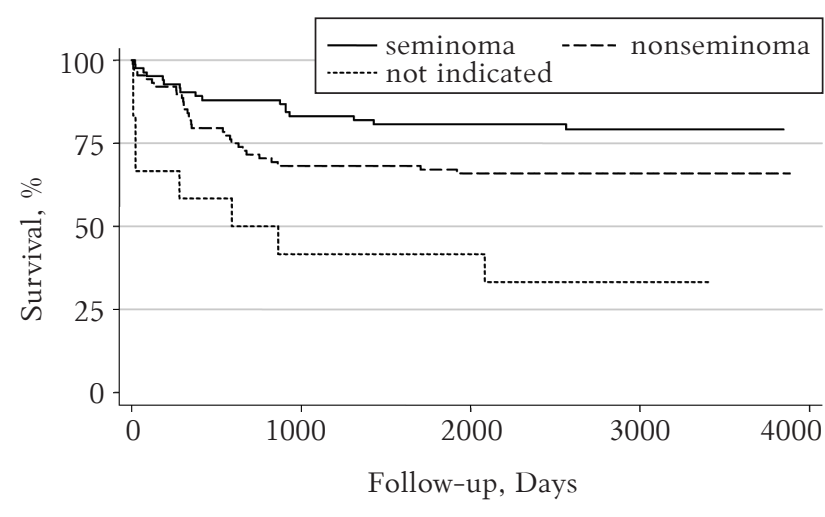

Fig. 2. The survival of patients diagnosed with testicular cancer in Lithuania during 1998-2002 according to tumor histological form

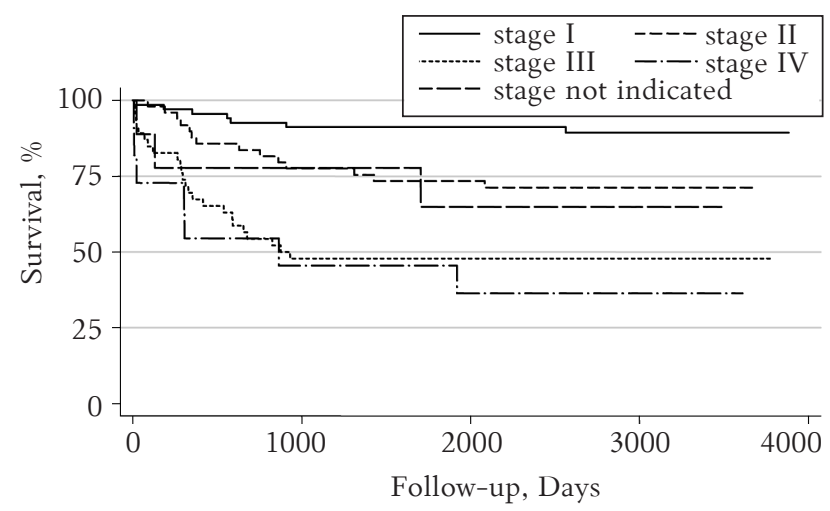

Fig. 3. The 5-year survival of patients diagnosed with testicular cancer in Lithuania during 1998-2002 by disease stage

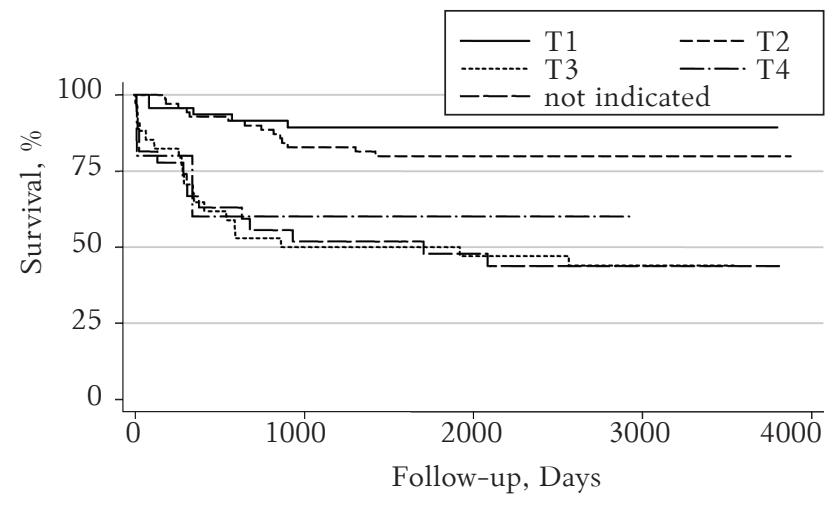

Fig. 4. The 5-year survival of patients diagnosed with testicular cancer in Lithuania during 1998-2002 by tumor size (T)

for TC among young men. Germ cell tumors are different from the majority of solid tumors found in adults since they derive from embryonic cells (contrary to other tumors) and thus are more frequently found in young than older men (6).

Germ cell testicular tumors are traditionally classified into seminomas (40\%) and nonseminomas $(60 \%)$ (4). Both groups actually possess different mode of treatment, prognosis, and survival. Nonseminoma category comprises different types of tu- 
mors (embryonic carcinoma, yolk sac tumor, teratoma, choriocarcinoma, etc.), including mixed cell type tumors (with or without seminoma component). Testicular stromal tumors (Leydig cells, Sertoli cells, granulosa cells, etc.) are found more rarely $(7,8)$. The growth of seminoma is slower and thus has a better prognosis than nonseminoma. Seminoma is sensitive to both radiotherapy and chemotherapy and has a good prognosis. Because of aggressive and rapid growth of nonseminomas, the age peak in those who are diagnosed with nonseminomas is 10 years earlier than in those with seminomas: the highest morbidity rates due to nonseminomas are observed in men aged 25-29 years, while due to seminomas, in men aged 35-39 years (9).

The survival of patients having neoplastic diseases commonly depends on multiple factors. The survival may be longer due to earlier diagnosis as well as effective treatment. The survival rates of country population do not only reflect the effectiveness of cancer treatment of certain localization, but they are also influenced by general diagnostic practice, treatment, observation of patients in existing health care system, methods of data collection and analysis, as well as tumor (histology, stage, and confirmation method) and patients' characteristics. The survival rates of population are important when evaluating the effectiveness of health care system and contribute to planning and evaluation of access to health care services in different regions of the country or different population groups (10).

The observed 5-year survival of patients with testicular cancer diagnosed in Lithuania during 1998-2002 was 71.2\% (95\% CI, 64.4\%-77.5\%). The survival for those diagnosed with TC is significantly better in other developed countries. According to the data of the EUROCARE-IV study, the relative 5-year survival in Europe was $94.2 \%$ in the early 1980s. However, poorer 5-year survival was documented in Baltic countries: the survival rate in Estonia (71.4\%) was similar to that in Lithuania (11). It is thought that the differences in age structure or tumor biology cannot be responsible for the established survival discrepancies among European countries.

The low survival rates of those diagnosed with TC in Lithuania cannot be associated with the prevalence of the histological forms of tumor - the proportion of diagnosed seminomas and nonseminomas is similar to other European countries. Among new cases of testicular malignant tumors diagnosed during 1998-2007, seminomas accounted for 44\%, nonseminomas for $33 \%$, and tumors with no histological form for $7 \%$ (12). In our opinion, the low survival rates might be influenced by the higher number of advanced TC in Lithuania due to late diagnosis. For instance, in the United Kingdom, stage I seminomas are diagnosed in $80 \%$ of patients and nonseminomas in approximately 60\%, while in Lithuania stage I TCs are found only in $37 \%$ of patients (13). In our study, advanced stage of the disease was a major factor that significantly deteriorated the survival.

The other possible determinant influencing the survival is appropriate treatment (adjuvant chemotherapy in the first place). The effect of treatment on those diagnosed with TC has not been analyzed in the study; however, in the future a thorough analysis should be carried out taking into account treatment. Such an analysis would allow for more accurate evaluation of the effectiveness of treatment in terms of modern TC treatment schemas and how much this treatment influences the low survival rates of patients with TC.

\section{Conclusions}

The 1-year survival of patients diagnosed with testicular cancer was $83.1 \%$ (95\% CI, 76.8\%-87.8\%), while the 5-year survival was $71.2 \% \quad(95 \%$ CI, $64.4 \%-77.5 \%)$. The results of the analysis by different demographical, pathological, and clinical characteristics revealed that the significant factors influencing the survival of patients diagnosed with testicular cancer in Lithuania were as follows: patient's age at the time of diagnosis, tumor histological form, stage, tumor size, the number of affected lymph nodes, and the presence of distant metastases.

\section{Susirgusiųjų sėklidžių vẻžiu 1998-2002 išgyvenamumas Lietuvoje}

\section{Agnius Juška ${ }^{1}$, Albertas Ulys ${ }^{2}$, Laura Kairevič $\dot{e}^{3}$, Giedrè Smailyte் $\dot{e}^{4}$ Edgaras Stankevičius ${ }^{5}$, Rasa Jančiauskiené $\dot{ }^{3}$, Mindaugas Jievaltas ${ }^{6}$}

\footnotetext{
${ }^{1}$ Vilniaus universiteto Medicinos fakultetas, ${ }^{2}$ Vilniaus universiteto Onkologijos instituto Onkochirurgijos centras, ${ }^{3}$ Lietuvos sveikatos mokslu universiteto Medicinos akademijos Onkologijos klinika, ${ }^{4}$ Vilniaus universiteto Onkologijos instituto Vėžio kontrolès ir profilaktikos centras, ${ }^{5}$ Lietuvos sveikatos mokslu universiteto Medicinos akademijos Fiziologijos katedra, ${ }^{6}$ Lietuvos sveikatos mokslu universiteto Medicinos akademijos Urologijos klinika
}

Raktažodžiai: sèklidžiu vėžys, išgyvenamumas, Kaplano-Meierio metodas, log-rank testas.

Santrauka. Tyrimo tikslas. Iૃvertinti 1998-2002 sẻklidžių vèžiu susirgusių pacientų išgyvenamumą ir jam reikšmingos įtakos turinčius veiksnius. 
Tyrimo medžiaga ir metodika. Išgyvenamumo tyrimui naudoti Lietuvos vèžio registro duomenys apie susirgusiuosius sẻklidžių vẻžiu 1998-2002. Pacientų, susirgusių sẻklidžių vėžiu, penkerių metų išgyvenamumas įvertintas Kaplano-Meierio metodu, o išgyvenamumui palyginti naudotas log-rank testas.

Rezultatai. Lietuvoje susirgusiųjų sẻklidžių vėžiu penkerių metų išgyvenamumas buvo 71,2 proc. (95 proc. PI 64,4-77,5). Šio tyrimo duomenimis, sẻklidžių vẻžiu susirgusiųjų išgyvenamumui reikšmingos įtakos turèjo paciento amžius diagnozės nustatymo metu, naviko histologinė forma ir stadija, kada diagnozuotas navikas (naviko dydis, pažeistų limfmazgių skaičius, tolimosios metastazės).

Išvada. Lietuvoje sẻklidžių vėžiu susirgusiųių išgyvenamumo rodikliai žymiai mažesni nei kitose Europos šalyse. Geresnis išgyvenamumas buvo susijęs su jaunesniu paciento amžiumi ir mažesniu naviko išplitimu.

\section{References}

1. Parkin DM, Bray F, Ferlay J, Pisani P. Global cancer statistics, 2002. CA Cancer J Clin 2005;55:74-108.

2. Ferlay J, Bray F, Pisani P, et al. GLOBOCAN 2000: cancer incidence, mortality and prevalence worldwide. IARC Cancer Base No. 5. Lyon: IARC; 2001.

3. Moller H, Evans H. Epidemiology of gonadal germ cell cancer in males and females. APMIS 2003;111:43-6.

4. Moller H, Friis S, Kjaer SK. Survival of Danish cancer patients 1943-1987. Male genital organs. APMIS 1993;Suppl $33: 122-36$

5. Schmoll HJ, Souchon R, Krege S, Albers P, Beyer J, Kollmannsberger $\mathrm{C}$, et al. European consensus on diagnosis and treatment of germ cell cancer: a report of the European Germ Cell Cancer Consensus Group (EGCCCG). Ann Oncol 2004;15:1377-99.

6. Moller H. Clues to the aetiology of testicular germ cell tumours from descriptive epidemiology. Eur Urol 1993;23: 8-13.

7. Richiardi L, Bellocco R, Adami HO, Barlow L, Hakulinen $\mathrm{T}$, Rahu M, et al. Testicular cancer incidence in eight northern European countries: secular and recent trends. Cancer Epidemiol Biomarkers Prev 2004;13:2157-66.

Received 23 Ferbruary 2010, accepted 6 January 2011 Straipsnis gautas 20100223 , priimtas 20110106
8. STATA 8.0, Stata Corporation, 2003; College Station, Texas 77845 USA.

9. Parkin DM, Whelan SL, Ferlay J. Cancer incidence in five continents. Lyon: IARC; 2002. vol. 8. Publication no. 155.

10. Berrino F, Micheli A, Sant M, Capocaccia R. Interpreting survival differences and trends. Tumouri 1997;83:9-16.

11. Sant M, Aareleid T, Berrino F, Bielska Lasota M, Carli PM, Faivre J, et al. EUROCARE-3: survival of cancer patients diagnosed 1990-94 - results and commentary. Ann Oncol 2003;14(Suppl 5):v61-118.

12. Smailytė G, Kačènienė A, Ulys A, Kardelis Ž. Sẻklidžiu vėžys Lietuvoje 1978-2007 metais: paamžinès sergamumo struktūros ir histologinių formų dažnumo pokyčiai. (Testicular cancer in Lithuanian during 1978-2007: changes in morbidity and frequency of histological forms.) Sveikatos mokslai 2009;19:2787-91.

13. Horwich A, Shipley J, Huddart R. Testicular germ-cell cancer. Lancet 2006;367:754-65.

14. Schmoll HJ, Jordan K, Huddart R, Laguna MP, Horwich A, Fizazi K, et al. Testicular seminoma: ESMO clinical recommendations for diagnosis, treatment and follow-up. Ann Oncol 2009;20(Suppl 4):83-9. 